\title{
STANISEAW KORDASIEWICZ
}

\author{
Uniwersytet Warszawski
}

\section{CUSTODIAM PRAESTARE - EWOLUCJA ZOBOWIAZZANIA DO STRZEŻENIA RZECZY W PRAWIE RZYMSKIM}

\section{WPROWADZENIE}

Interpretacja zwrotu custodiam praestare mimo licznych badań nad rzymską odpowiedzialnością kontraktową pozostaje problemem otwartym. W wielu tekstach custodiam praestare wydaje się określać obowiązek strzeżenia rzeczy. W tej grupie źródeł rozważane są granice zobowiązania do strzeżenia, stawia się pytania odnośnie konieczności strzeżenia niewolników czy możliwości uniknięcia przez strzeżenie (custodia) określonych zdarzeń. W oparciu o ten materiał część doktryny interpretuje custodiam praestare jako typowe zobowiązanie kontraktowe i przypisuje dłużnikowi odpowiedzialność zgodnie z ogólnymi zasadami, na podstawie niezachowania należytej staranności w strzeżeniu.

Z drugiej strony istnieje jednak szereg tekstów, w których custodiam praestare występuje wspólnie z innymi określeniami odczytywanymi jako kryteria odpowiedzialności kontraktowej (culpam, dolum praestare). Kontkekst w jakim w tej grupie tekstów znajduje się omawiana konstrukcja, wskazuje z reguły na odpowiedzialność niezależną od winy dłużnika, przypisywaną za sam fakt zaistnienia określonych zdarzeń, w szczególności, za utratę rezczy w wyniku kradzieży. Doktryna w oparciu o tę grupę tekstów wykluczyła istnienie zobo- 
wiązania do strzeżenia rzeczy określanego przez custodiam praestare i stworzyła teorię obiektywnej odpowiedzialności za custodia.

Najnowsze ujęcia dogmatyczne problemu starają się podążać drogą pośrednią. Akceptują zarówno znaczenie custodiam praestare jako zobowiązania do strzeżenia rzeczy (custodia oznacza strzeżenie), dostrzegając jednak odpowiedzialność niezależną od staranności dłużnika.

Zobowiązanie do strzeżenia i powiązana z nim szczególna odpowiedzialność powstawała $z$ reguły wówczas, gdy przyjmowało się cudzą rzecz we własnym interesie. Sytuacja taka miala miejsce w wielu kontraktach, przede wszystkim w przypadku użyczenia (commodatum), w którym komodatariusz otrzymywał bezpłatnie rzecz do korzystania, w kontrakcie najmu rzeczy (locatio conductio rei), czy najmu usług (locatio conductio operis). Zobowiązanie do strzeżenia nie powstawało w kontrakcie depozytu, ponieważ osoba przyjmująca rzecz nie miala własnego interesu w przechowywaniu.

Celem mojego artykułu jest prześledzenie ewolucji zobowiązania do strzeżenia rzeczy. Jego granice były sporne już w czasach najdawniejszych prawników. Na podstawie analizy wybranych źródeł postaram się pokazać stopniowe rozszerzanie zakresu obowiązku określane go przez custodiam praestare. Klamrą tego procesu byto wprowadzenie w prawie poklasycznym odpowiedzialności dłużnika za staranność w strzeżeniu (diligentia in custodiendo) i odejście od modelu zobowiązania o charakterze gwarancyjnym. Zmiana dokonana w celu uzyskania spójności zasad odpowiedzialności kontraktowej wewnątrz kodyfikacji Justyniańskiej okazała się zmianą czysto terminologiczną. Dłużnik, choć pozornie odpowiadał za winę czy nienależytą staranność w strzeżeniu, mógł uwolnić się od odpowiedzialności jedynie przez wykazanie, że szkoda była spowodowana działaniem sily wyższej.

2. CUSTODIAM PRAESTARE W MYŚLI NAJDAWNIEJSZYCH PRAWNIKÓW

Jedynymi przekazami zawierającymi opinię najdawniejszych prawników na temat zobowiązania do strzeżenia rzeczy są dwa 
fragmenty pochodzące $\mathrm{z}$ długiego komentarza Ulpiana, dotyczącego odpowiedzialności komodatariusza ${ }^{1}$. W pierwszym tekście rozważane jest istnienie zobowiązania do strzeżenia użyczonego niewolnika:

D. 13,6,5,6 (Ulp. 28 ad ed.): Sed an etiam hominis commodati custodia praestetur, apud veteres dubitatum est. nam interdum et hominis custodia praestanda est, si vinctus commodatus est, vel eius aetatis, ut custodia indigeret: certe si hoc actum est, ut custodiam is qui rogavit praestet, dicendum erit praestare ${ }^{2}$.

Ulpian przekazuje wątpliwość najdawniejszych prawników, czy zobowiązanie do strzeżenia obejmuje także przypadek użyczenia niewolnika. Zdaniem veteres strzeżenie niewolnika należało zagwarantować jedynie jeżeli został on użyczony w kajdanach (si vinctus commodatus est) albo był w wieku wymagającym ochrony (vel eius aetatis, ut custodia indigeret). Zobowiązanie do strzeżenia mogło powstać także na mocy ustaleń z komodatariuszem podczas zawierania transakcji (si hoc actum est, ut custodiam is qui rogavit praestet).

W drugim tekście analizowane są granice zobowiązania do strzeżenia rzeczy:

D. 13,6,5,9 (Ulp. 28 ad ed.): Usque adeo autem diligentia in re commodata praestanda est, ut etiam in ea, quae sequitur

${ }^{1}$ Chodzi o fragment D. 13,6,5,2-10. Ulpian określa w nim kryteria odpowiedzialności komodatariusza, zestawiając ten kontrakt z innymi kontraktami (D. 13,6,5,2), podkreślając jednostronność korzyści komodatariusza (D. 13,6,5,3) oraz wskazując szczególne zasady odpowiedzialności na podstawie rozbudowanej kazuistyki (D. $13,6,5,4 ; 7-8 ; 10)$.

${ }^{2}$ Wśród najdawniejszych prawników powstała wątpliwość, czy należy strzec także użyczonego niewolnika. W istocie czasami powstaje konieczność strzeżenia niewolnika, na przykład jeżeli został użyczony w kajdanach, albo jest w tym wieku, który wymaga ochrony; także z pewnością wtedy, gdy w transakcji zostało uzgodnione, że ten kto prosił o niewolnika będzie świadczyl jego ochronę, będzie zobowiązany (do strzeżenia). 
rem commodatam, praestari debeat: ut puta equam tibi commodavi, quam pullus comitabatur: etiam pulli te custodiam praestare debere veteres responderunt ${ }^{3}$.

Ulpian rozpoczyna od wyrażenia ogólnej reguly: zachowanie staranności względem rzeczy użyczonej obejmuje także staranność względem rzeczy towarzyszącej przedmiotowi użyczenia (quae sequitur rem commodatam). Przykładem powyższej sytuacji jest użyczenie klaczy ze źrebakiem. Najdawniejśni prawnicy utrzymywali, że obowiązek strzeżenia dotyczy nie tylko użyczonej klaczy, lecz rozciąga się także na podążającego z nią źrebaka.

W tekście bardzo wyraźna jest rozbieżność terminologiczna. $\mathrm{Na}$ początku wypowiedź Ulpiana dotyczy staranności względem rzeczy użyczonej (diligentia in re commodata praestanda est), podczas gdy w ostatnim zdaniu, będącym przecież egzemplifikacją wyrażonej poprzednio generalnej reguły, spotykamy obowiązek strzeżenia rzeczy niezależny od staranności (custodiam praestare debere veteres responderunt). Problem interpolacji w tekstach dotyczących zobowiązania do strzeżenia zostanie podjęty w ostatniej części artykułu. W tym miejscu wystarcza podkreślić, że w przytoczonych źródłach veteres $^{4}$ posługują się wylącznie kategorią zobowiązania do strzeżenia, określanego przez custodiam praestare.

Problemem rozważanym przez najdawniejszych prawników w analizowanych źródłach jest zakres zobowiązania do strzeżenia.

${ }^{3}$ Względem użyczonej rzeczy należy zachowywać tak daleką staranność, że nie obejmuje ona tylko jej samej, ale konieczne jest zachowanie staranności także względem każdej innej rzeczy, która pozsostaje z nią bezpośrednio związana, np. jeżeli użyczam tobie klacz, której towarzyszy źrebak: najdawniejsi prawnicy odpowiadali, że jesteś także zobowiązany do strzeżenia źrebaka.

${ }^{4}$ Zdaniem R. CARDILLI, L'obbligazione di 'praestare' e la responsabilità contrattuale in diritto romano, Milano 1995, s. 170, z dużą dozą prawdopodobieństwa możemy określić veteres jako prawników żyjących w II-I w. p.n.e. Autor wskazuje między innymi, że Ulpian wymienia w D. 7,8,10,3 Rutiliusa Rufusa wśród veteres oraz określa Sabinusa w D. 12,5,6 jako kontynuatora opini najdawniejszych prawników. 
W pierwszym tekście Ulpian przywoluje wątpliwość veteres dotyczącą konieczności strzeżenia użyczonego niewolnika. Rozumowanie jurystów wskazuje na nietypowość takiego obowiązku, powstającego w szczególnych sytuacjach: jeżeli niewolnik został użyczony w kajdanach $^{5}$, jeżeli jest w wieku który wymaga ochrony ${ }^{6}$ oraz jeżeli zostało to uzgodnione między stronami. Za interpolacją ostatniej hipotezy opowiadał się Arangio-Ruiz. Autor ten wskazywal, że umowa stron dotycząca odpowiedzialności za custodia byłaby wyrazem poklasycznej tendencji do jej subiektywizacji ${ }^{7}$. Wydaje się jednak, że jest to zarzut niesłuszny, ponieważ strony mogły samodzielnie kształtować zakres odpowiedzialności prawnej. Cannata przekonująco argumentuje, że skoro veteres przywiązywali wagę do woli właściciela wyrażonej przez sam fakt oddania niewolnika w kajdanach, to tym bardziej akceptowali umowne postanowienia stron ${ }^{8}$.

Kwestia konieczności strzeżenia niewolników w prawie rzymskim jest bardzo złożona i była przedmiotem sporów w doktrynie ${ }^{9}$.

${ }^{5}$ Obowiązek strzeżenia, w przypadku użyczenia niewolnika w kajdanach, może z prawnego punktu widzenia być ujęty jako realizacja dorozumianego nakazu wlaściciela (obowiązkiem komodatariusza jest korzystanie z rzeczy zgodnie z jego wolą), bądź może wynikać z konieczności zwrotu rzeczy w niezmienionym stanie. R. CARDILli, L'obbligazione di 'praestare' (cit. przyp. 4), s. 180 wskazuje, że samo zdjęcie kajdan może być kradzieżą, por. D. 4,3,7,7 (Ulp. 11 ad ed.): Idem Labeo quaerit, si compeditum servum meum ut fugeret solveris, an de dolo actio danda sit? et ait Quintus apud eum notans: si non misericordia ductus fecisti, furti teneris: si misericordia, in factum actionem dari debere;

${ }^{6}$ Użyczenie niewolnika wymagającego ochrony ze względu na wiek wiązało się bezpośrednio z obowiązkiem strzeżenia po stronie komodatariusza. Wprawdzie źródlo nie precycuje w jakim wieku niewolnicy wymagają ochrony, jednak dla najdawniejszych prawników jest to kategoria jednoznaczna i zdaje się mieć charakter obiektywny.

${ }^{7}$ V. ARANGIO-RuIZ, Responsabilità contrattuale in diritto romano, Napoli, Jovene 1933 [2 ed. rist. 1958], s. 169. R. CARDILI, L'obbligazione di 'praestare' (cit. przyp. 4), s. 173 w swojej pracy pomija ten fragment nie podając uzasadnienia.

${ }^{8}$ C. A. CANNATA, Ricerche sulla responsabilità contrattuale nel diritto romano, I, Milano1966, s. 48.

${ }^{9}$ Odniesienia do dawniejszej literatury w V. ARANGIO-RuIZ, Responsabilità (cit. przyp. 7), s. 169-170; C. A. CANnATA, Ricerche (cit. przyp. 8), s. 46 
Ucieczka niewolnika określonej kategorii była traktowana w prawie rzymskim jako siła wyższa ${ }^{10}$. Kaser zauważa, iż z samej istoty niewolnictwa wynika przypisane zazwyczaj właścicielowi ryzyko ucieczki niewolnika ${ }^{11}$. Wyjątkiem od tej reguły są niewolnicy wymagający strzeżenia ze względu na skłonność do ucieczki, na wiek bądź ewentualne inne okoliczności ${ }^{12}$. Na podstawie dostępnego materiału źródłowego wydaje się, że zazwyczaj niewolnik jako istota rozumna nie wymagał ciągłego dozoru. Posiadanie niewolników jako sily roboczej byłoby nieracjonalne z ekonomiczengo punktu widzenia, gdyby istniała konieczność zapewnienia bardzo kosztownej i kłopotliwej w praktyce ochrony przed ucieczką.

W drugim z przytaczanych tekstów pytanie najdawniejszych jurystów dotyczyło granic obowiązku strzeżenia: czy rozciąga się on także na rzecz bezpośrednio związaną z przedmiotem użyczenia? W przypadku użyczenia klaczy wraz ze źrebakiem, komodatariusz był zdaniem veteres zobowiązany do strzeżenia także towarzyszącego jej potomstwa ${ }^{13}$.

$\mathrm{Z}$ analizowanych źródeł wynika, że najdawniejsi prawnicy dostrzegali obowiązek strzeżenia rzeczy ciążący na komodatariuszu ${ }^{14}$.

${ }^{10}$ D. 50,17,23 (Ulp. 29 ad Sab.): ... animalium vero casus mortesque, quae sine culpa accidunt, fugae servorum qui custodiri non solent, rapinae, tumultus, incendia, aquarum magnitudines, impetus praedonum a nullo praestantur.; por. też D. $13,6,18$ pr.

${ }^{11}$ M. KASER, Die 'actio furti' des Verkäufers, «ZSS» 96 (1979), s. 110.

${ }^{12}$ C.A. Cannata, Ricerche (cit. przyp. 8), s. 47; por. też D. 6,1,21 i D. 6,1,36,1.

${ }^{13} \mathrm{O}$ tym że zainteresowanie komodatariusza ogranicza się do klaczy świadczy fakt, że źrebak jest traktowany jako rzecz jej towarzysząca, nie stanowi odrębnego przedmiotu użyczenia. Rozciągnięcie obowiązku strzeżenia na rzecz towarzyszącą chroni interesy właściciela, ale ten ostatni w innym przypadku mógłby zrezygnować zawierania kontraktu.

${ }^{14}$ A. Metro, L'obbligazione di custodire nel diritto romano, Milano 1966, s. 101 i 151-152 wyklucza istnienie zobowiązania do strzeżenia w D. 13,6,5,6. Wbrew poglądom tego autora, należy podkreślić, że podział niewolników na kategorie servi qui custodiri solent i servi qui custodiri non solent, choć abstrakcyjny, nie sluży przypisywaniu obiektywnego kryterium odpowiedzialności, jakim zresztą nigdy nie by- 
Problemem było jedynie odnalezienie granic tego zobowiązania nie zaś samo jego istnienie.

Zamykając rozważania odnośnie zobowiązania do strzeżenia w myśli najdawniejszych prawników można postawić pytanie, dlaczego jego historia powiązana jest $\mathrm{z}$ kontraktem użyczenia ${ }^{15}$. Kontrakt ten zapewnia możliwość nieodpłatnego używania cudzej rzeczy. Obowiązek strzeżenia rzeczy oceniany w kategoriach rezultatu - a więc niezależnie od staranności dłużnika - wprowadzał w jakiejś mierze równowagę wobec jednostronnej korzyści komodatariusza ${ }^{16}$.

\section{CUSTODIAM PRAESTARE JAKO ZOBOWIAZZANIE GWARANCYJNE}

Gwarancyjny charakter zobowiązania do strzeżenia jest widoczny w poniższym tekście Gaiusa, pochodzącym z 5 księgi komentarza do edyktu prowincjonalnego ${ }^{17}$. Jurysta analizuje relację między otrzymywanym wynagrodzeniem a zobowiązaniem do strzeżenia:

D. 19,2,40 (Gai. 5 ad ed. prov.) Qui mercedem accipit pro custodia alicuius rei, is huius periculum custodiae praestat.

D. 4,9,5 pr. (Gai. 5 ad ed. prov.) Nauta et caupo et stabularius mercedem accipiunt non pro custodia, sed nauta ut traiciat vectores, caupo ut viatores manere in caupona patiatur, stabularius ut permittat iumenta apud eum stabulari: et tamen

la custodia. Niewolnicy określani jako servi qui custodiri solent to po prostu niewolnicy, których trzeba strzec.

${ }^{15} \mathrm{Nie}$ mamy pewności czy w istocie veteres wiązali zobowiązanie do strzeżenia jedynie z tym kontraktem.

${ }^{16}$ Pierwsze poświadczone zobowiązanie do strzeżenia mają za przedmiot niewolnika i konia. R. CARDILLI, L'obbligazione di 'praestare' (cit. przyp. 4), s. 182 podkreśla ogromną wartość, jaką przedstawiały one dla Rzymian w okresie republikańskim.

${ }^{17}$ O. Lenel, 'Palingenesia Iuris Civilis', I, Leipzig 1889, szp. 198 nr 119. 
custodiae nomine tenentur nam et fullo et sarcinator non pro custodia, sed pro arte mercedem accipiunt, et tamen custodiae nomine ex locato tenentur ${ }^{18}$.

Gaius na wstępie stwierdza, że ten, kto otrzymał zapłatę za strzeżenie rzeczy (mercedem accipit pro custodia), ponosi ryzyko związane $\mathrm{z}$ jej strzeżeniem (periculum custodiae praestat). W drugim fragmencie przeciwstawione zostają zobowiązania, w których ochrona nie jest podstawowym świadczeniem dlużnika, a obecna jest odpowiedzialność za strzeżenie rzeczy. I tak żeglarz (nauta) otrzymuje wynagrodzenie za transport towarów, właściciel zajazdu (caupo) za udostępnienie schronienia podróżnym, właściciel stajni (stabularius) za trzymanie w niej zwierząt - jednak wszyscy wymienieni są mimo to zobowiązani do i odpowiedzialni za strzeżenie rzeczy (et tamen custodiae nomine tenentur). Aby wyjaśnić powyższe, Gaius przytacza przykład krawca i folusznika. Otrzymują oni wynagrodzenia nie za ochronę, lecz za świadczone usługi (non pro custodia, sed pro arte mercedem accipiunt), a jednak odpowiadają za strzeżenie rzeczy na podstawie actio locati (et tamen custodiae nomine ex locato tenentur).

Analizowane źródło dowodzi, że dla Gaiusa custodia była treścią zobowiązania. W pierwszej części tekstu strzeżenie cudzej rzeczy stanowi jedyne świadczenie dłużnika, za które otrzymywane jest wynagrodzenie. Następnie custodia jest wymieniana obok innych możliwych świadczeń, takich jak przewóz towarów, udostępnienie schronienia podróżnym czy opieka nad zwierzętami. Jurysta podkreśla, że osoby objęte edyktem de receptis otrzymują wynagrodzenie za świadczone usługi, a nie za strzeżenie rzeczy. Jed-

${ }^{18}$ Kto otrzymał zapłatę za strzeżenie czyjejś rzeczy ponosi ryzyko związane ze strzeżeniem rzeczy. Żeglarz, właściciel zajazdu, właściciel stajni otrzymują zapłatę nie za strzeżenie, lecz żeglarz za transport pasażerów, właściciel zajazdu za to, że pozawala podróżnym korzystać z zajazdu, właściciel stajni za to, że pozawala trzymać w stajni zwierzęta, a jednak są zobowiązani do/odpowiedzialni za strzeżenie rzeczy; bowiem i folusznik i krawiec nie za ochronę lecz za usługi biorą oplatę, a jednak można ich pozwać actio locati z powodu nieustrzeżenia rzeczy. 
nak również w wymienionych przypadkach istnieje zobowiązanie do strzeżenia i powiązana z nim odpowiedzialność (Nauta et caupo et stabularius mercedem accipiunt non pro custodia ... et tamen custodiae nomine tenentur).

Zwraca uwagę płynność z jaką dla badacza zakorzenionego w kategoriach współczesnego prawa zmieniają się zakresy znaczeniowe custodia. Dla Gaiusa custodiam praestare stanowiło spójną konstrukcję dogmatyczną, określającą zarówno zobowiązanie jak i odpowiedzialność. Zobowiązanie do strzeżenia i odpowiedzialność za strzeżenie stanowią po prostu dwa aspekty tego samego zjawiska, są niczym awers i rewers jednej monety. W tej perspektywie nieporozumieniem wydają się wspólczesne wypowiedzi usiłujące rozbić znaczenie jakie dla rzymskiej jurysprudencji posiadało zobowiązanie do strzeżenia, określane przez custodiam praestare ${ }^{19}$.

Podstawowym problemem jaki stawia sobie jurysta w analizowanym tekście jest określenie, kiedy powstaje zobowiązanie do strzeżenia rzeczy i wynikająca $\mathrm{z}$ niego odpowiedzialność?

Zobowiązanie takie powstaje bez wątpienia wówczas, gdy osoba otrzymuje wynagrodzenie za strzeżenie rzeczy. Gaius mówi o ponoszeniu ryzyka związanego ze strzeżeniem rzeczy (periculum custodiae $)^{20,21}$.

${ }^{19}$ Por. A. Metro, 'Custodiam praestare', «Labeo» 13 (1967), s. 63

${ }^{20}$ Jest prawdopodobne, że w wyniku rozwoju myśli rzymskiej jurysprudencji nastąpiła ewolucja od ujmowania problemów odpowiedzialności w kategorii ogólnego ryzyka (periculum), poprzez wydzielenie szczególnego typu ryzyka związanego ze strzeżeniem rzeczy (periculum custodiae), tożsamego z gwarancyjnym zobowiązaniem do strzeżenia rzeczy określanym przez custodiam praestare - pierwotnie zakres zobowiązania mógł być ograniczony tylko do kontraktu użyczenia. Por. np. poniższy tekst Ulpiana, w którym precyzuje on wypowiedź Juliana operującego jeszcze ogólną kategorią ryzyka. Ulpian posługuje się już zobowiązaniem do strzeżenia (custodiam praestare) - D. 16,3,1,35 (Ulp. 30 ad ed.).

${ }^{21}$ Por. C.A. CANnATA, Sul problema della responsabilità nel diritto privato romano, «Iura» 42-43 (1992-3), s. 55; zdaniem F.M. DE ROBERTIs, La responsabilità contrattuale nel diritto romano (dalle origini a tutta l'età postclassica), Bari 1994, s. 183, podstawowe w jego rekonstrukcji kryterium odpowiedzialności (periculum) najczęściej 
W dalszej części tekstu Gaius wyjaśnia istnienie zobowiązania do strzeżenia nałożone na osoby objęte edyktem de receptis, które nie otrzymują za strzeżenie rzeczy wynagrodzenia. Powiada, że folusznik i krawiec otrzymują wynagrodzenie za świadczone usługi, a nie za strzeżenie. Niezależnie od tego są zobowiązani do strzeżenia rzeczy i ponoszą wynikającą z tego odpowiedzialność (nam et fullo et sarcinator non pro custodia, sed pro arte mercedem accipiunt, et tamen custodiae nomine ex locato tenentur).

Wyjaśnienie Gaiusa mogłoby być uznane za mało przekonujące. Pozornie opiera się bowiem na schemacie ignotum per ignotum. Ta$\mathrm{ka}$ interpretacja nie jest jednak poprawna. Analizując ten tekst musimy mieć na uwadze znaczenie jakie dla jurysty posiadają przytoczone przykłady. Zobowiązanie do strzeżenia ciążące na fullo i sarcinator Gaius wyjaśnia dokładnie w G. 3,205-207. Jest to jedno z najczęściej analizowanych źródeł w badaniach rzymskiej odpowiedzialności kontraktowej.

\section{ZNACZENIE CUSTODIAM PRAESTARE W INSTYTUCJACH GAIUSA}

Omawiany poniżej tekst stanowi część wywodu dotyczącego dostępności actio furti. Jurysta rozpoczyna od przedstawienia generalnej zasady: powództwo z tytułu kradzieży przysługuje temu, kto ma interes, by rzecz nie została utracona, chociażby nie był właścicielem ${ }^{22}$. Pierwszym przykładem takiej osoby jest wierzyciel zastawny ${ }^{23}$. Następnie Gaius analizuje inne kontrakty, rozważając problem dostęp-

funkcjonowało w przypadku nieustrzeżenia rzeczy; podobnie R. CARDILLI, L'obbligazione di 'praestare' (cit. przyp. 4), s. 490.

${ }^{22}$ Zdaniem Gaiusa, skarga przysluguje wlaścielowi wylącznie wtedy, gdy ma on interes w tym by nie utracić rzeczy - G. 3,203: Furti autem actio ei conpetit, cuius interest rem saluam esse, licet dominus non sit. itaque nec domino aliter conpetit, quam si eius intersit rem non perire.

${ }^{23}$ G. 3,204: Unde constat creditorem de pignore subrepto furti agere posse; adeo quidem, ut quamuis ipse dominus [id est ipse debitor] eam rem subripuerit, nihilo minus creditori conpetat actio furti. 
ności actio furti w kontekście leżącego u jej podstawy interesu zachowania rzeczy (rem salvam esse):

G. 3,205-206: Item si fullo polienda curandave aut sarcinator sarcienda vestimenta mercede certa acceperit eaque furto amiserit, ipse furti habet actionem, non dominus, quia domini nihil interest ea non periisse, cum iudicio locati a fullone aut sarcinatore suum consequi possit, si modo is fullo aut sarcinator rei praestandae sufficiat; nam si solvendo non est, tunc quia ab eo dominus suum consequi non potest, ipsi furti actio conpetit, quia hoc casu ipsius interest rem salvam es$s e^{24}$. 206. Quae de fullone aut sarcinatore diximus, eadem transferemus et ad eum, cui rem commodavimus. nam ut illi mercedem capiendo custodiam praestant, ita hic quoque utendi commodum percipiendo similiter necesse habet $\mathrm{cu}$ stodiam praestare ${ }^{25}$.

W G. 3,205 autor Instytucji omawia kontrakty locatio-conductio zawierane $\mathrm{z}$ folusznikiem oraz krawcem. Jeżeli otrzymali wynagrodzenie za świadczone usługi i rzecz została im skradziona, będą mogli sami wnieść skargę z tytułu kradzieży. Gaius argumentuje zgodnie z wyrażoną wcześniej zasadą ogólną (G. 3,203), że w analizowanej sytuacji wlaściciel nie ma interesu by rzecz nie została skradzio-

${ }^{24}$ Podobnie jeżeli folusznik otrzymal wynagrodzenie za czyszczenie lub krawiec za naprawę ubrania, a zostały one skradzione, skarga z tytułu kradzieży będzie przysługiwala im wylącznie, nie zaś wlaściecielowi. Nie ma on bowiem interesu w tym, by rzecz nie została skradziona, ponieważ może uzyskać swoje od folusznika lub krawca wnosząc skargę kontraktową, o ile folusznik i krawiec są w stanie świadczyć wartość rzeczy. Jeżeli jednak nie są wypłacalni, tak że właściciel nie może od nich uzyskać swoich należności, jemu (właścicielowi) będzie przysługiwała skarga z tytułu kradzieży, gdyż w tym przypadku (niewypłacalności dłużnika) sam posiada interes w tym by rzecz pozostała nietknięta.

${ }^{25}$ To co powiedzieliśmy o foluszniku i krawcu możemy odnieść także do tego, komu rzecz oddaliśmy w użyczenie. Gdyż jak tamci zobowiązani są do strzeżenia rzeczy ze względu na otrzymywane wynagrodzenie, tak ten ze względu na korzyści używania ma podobnie obowiązek strzeżenia rzeczy. 
na: może bowiem odzyskać od dłużnika wartość rzeczy wnosząc skargę kontraktową (cum iudicio locati a fullone aut sarcinatore suum consequi possit). Ograniczeniem przedstawionego schematu dostępności skargi z tytułu kradzieży jest stan niewypłacalności dłużnika. Wówczas actio furti powraca do właściciela, ponieważ nie mogąc uzyskać należności od kontrahenta, sam staje się zainteresowany w tym, by rzecz pozostała nietknięta.

Powyższe rozważania Gaius rozciąga także na osobę komodatariusza. Podobnie jak folusznik i krawiec ze względu na otrzymywane wynagrodzenie mają obowiązek strzeżenia rzeczy, tak komodatariusz ze względu na nieodpłatną korzyść używania przekazanej mu rzeczy jest zobowiązany do strzeżenia. Dostępności actio furti dla dłużników w analizowanych powyżej kontraktach Gaius przeciwstawia pozycję depozytariusza:

G. 3,207: Sed is, apud quem res deposita est, custodiam non praestat tantumque in eo obnoxius est, si quid ipse dolo malo fecerit; qua de causa si res ei subrepta fuerit, quia restituendae eius nomine depositi non tenetur nec ob id eius interest rem saluam esse, furti [itaque] agere non potest, sed ea actio domino conpetit ${ }^{26}$.

Jurysta stwierdza, że depozytariusz nie jest zobowiązany do strzeżenia rzeczy. Jest zaś zobowiązany wyłącznie co do tego, co sam uczyni podstępnie. Jeżeli więc rzecz zostałaby mu ukradziona, to nie będąc odpowiedzialnym z tej przyczyny za jej zwrócenie, ani nie posiadając własnego interesu $\mathrm{w}$ tym, by rzecz pozostała nietknięta, nie ma możliwości wniesienia skargi z tytułu kradzieży. Actio furti w przypadku zawarcia kontraktu depozytu przysługuje nadal właścicielowi.

${ }^{26}$ Lecz depozytariusz nie jest zobowiązany do strzeżenia rzeczy. Jest zobowiązany wyłącznie w stosunku do tego, co by sam uczynił podstępnie. Z tej też przyczyny, jeżeli rzecz zostala mu skradziona, ponieważ nie odpowiada z tego tytulu za jej oddanie ani nie ma interesu w tym by rzecz pozostała nietknięta, nie może posłużyć się skargą z tytułu kradzieży, lecz będzie ona przysługiwała właścicielowi. 
Analizę G. 3,205-7 rozpocznę od przedstawienia najbardziej wpływowej interpretacji Vincenzo Arangio-Ruiza. Zdaniem tego autora nie posiadamy żadnych innych wiarygodnych informacji na temat zasad odpowiedzialności kontraktowej prawa klasycznego ${ }^{27}$. Rekonstrukcja dokonana na podstawie omawianego źródła ostatecznie ugruntowała interpretację custodia jako obiektywnego kryterium odpowiedzialności. Odpowiedzialność taka obciążała folusznika i krawca (locatio conductio operis), natomiast nie dotyczyła depozytariusza. Osoba odpowiedzialna za custodia była zobowiązana do zwrotu rzeczy (bądź jej równowartości) także wówczas, gdy rzecz zostałaby skradziona ${ }^{28}$.

Arangio-Ruiz podkreśla, że dla Gaiusa nie są istotne okoliczności utraty rzeczy. Podstawę odpowiedzialności stanowi sam fakt kradzieży w czasie, gdy rzecz znajdowała się u osób odpowiedzialnych za custodia. Odpowiedzialność krawca, folusznika i komodatariusza jest niezależna od winy. Autor stwierdza ponadto, że obiektywnej odpowiedzialności za custodia jurysta przeciwstawia wyłącznie subiektywną odpowiedzialność za podstęp (dolus). Fakt ten zdaniem Arangio-Ruiza świadczy o tym, że Gaius nie operował najistotniejszym współcześnie kryterium odpowiedzialności jakim jest wina $(\text { culpa })^{29}$.

Przedstawionej powyżej interpretacji nie podziela Francesco De Robertis $^{30}$. Punktem wyjścia dla ponownej analizy G. 3,205-207 jest zrozumienie, jak możliwe było przejście od źródłowego obowiązku strzeżenia rzeczy określonego przez custodia, do stworzenia obiektywnego kryterium odpowiedzialności ${ }^{31}$. Zdaniem autora, zwolennicy interpretacji custodia jako obiektywnego kryterium odpowie-

${ }^{27}$ V. ARANGIO-Ruiz, Responsabilità contrattuale (cit. przyp. 7), s. 65.

${ }^{28}$ V. ArAngto-Rutz, Responsabilità contrattuale (cit. przyp. 7), s. 66.

${ }^{29}$ V. ARANGIO-Ruiz, Responsabilità contrattuale (cit. przyp. 7), s. 66.

${ }^{30}$ Por. F.M. DE RoBertis, La responsabilità contrattuale (cit. przyp. 21), s. 344-363. Autor kwestionuje możliwość rekonstrukcji całego systemu odpowiedzialności na podstawie G. 3,205-207.

${ }^{31}$ F. M. DE RoBeRTIs, La responsabilità contrattuale (cit. przyp. 21), s. 330. 
dzialności błędnie obciążają dłużnika odpowiedzialnością za sam fakt kradzieży ${ }^{32}$. Kradzież jest przypadkiem niespełnienia zobowiązania do strzeżenia rzeczy, a nie zdarzeniem, za które rzymscy juryści przypisywali w oderwaniu od samego obowiązku ochrony obiektywną odpowiedzialność nazywając ją custodia.

Zdaniem De Robertisa custodia wyraża w analizowanym fragmencie obowiązek strzeżenia rzeczy. Odpowiedzialność dłużnika opiera się na samym fakcie niespełnienia zobowiązania. Zdefiniowane przez Arangio-Ruiza kryterium odpowiedzialności obiektywnej za kradzież jakim miała być custodia, De Robertis zastępuje o wiele szerszym kryterium ryzyka (periculum), wiążącym w sposób bezpośredni odpowiedzialność dłużnika z samym faktem niespełnienia należnego świadczenia ${ }^{33}$.

Podobnie interpretuje omawiany fragment Riccardo Cardilli w L'obbligazione di 'praestare' e la responsabilità contrattuale in diritto romano. Custodia stanowi dla tego autora zobowiązanie do strzeżenia rzeczy, a odpowiedzialność jest pochodną nakładanego przez jurystów obowiązku stania się gwarantem (praestare - stare praes). Autor zwraca uwagę na wyjaśnienia Gaiusa, odnośnie przejścia interesu zachowania rzeczy (rem salvam esse) i powiązanej z nim dostępności actio furti z osoby właściciela na określone kategorie dłużników. Cardilli wskazuje, że skarga z tytułu kradzieży zostaje przyznana folusznikowi, krawcowi czy komodatariuszowi ze względu na obowiązek custodiam praestare. Obowiązek strzeżenia był zaś przypisywany w oparciu o osiągane przez dłużnika korzyści z kontraktu ${ }^{34}$. Niezwykle istotne jest wskazanie roli, jaką w Instytucjach Gaiusa odgrywa przeciwstawienie sytuacji depozytariusza. Arangio-Ruiz interpretowal je jako podkreślenie, że obiektywna odpowiedzialność za custodia nie powstaje w każdym kontrakcie, w którym oddajemy naszą rzecz osobie

${ }^{32}$ F. M. DE RoBERTIS, La responsabilità contrattuale (cit. przyp. 21), s. 332.

${ }^{33}$ F. M. DE RoBERTIS, La responsabilità contrattuale (cit. przyp. 21), s. 335.

${ }^{34}$ R. CARDILli, L'obbligazione di 'praestare' (cit. przyp. 4), s. 488. 
trzeciej ${ }^{35}$. Cardilli stwierdza, iż prawdziwym motywem wyjaśnień jurysty nie jest problem odpowiedzialności. Gaius w swoim podręczniku pokazywał studentom, że źródłem zobowiązania określanego przez custodiam praestare nie jest faktyczna ochrona roztaczana nad rzeczą (custodia), lecz leżące u podstawy kontraktu interesy - czy inaczej odnoszone korzyści - stron. Depozytariusz, mimo oddania mu rzeczy właśnie w celu jej strzeżenia, ze względu na to, iż nie odnosi z kontraktu żadnej korzyści, nie ma szczególnego prawnego obowiązku strzeżenia rzeczy (custodiam non praestat). Cardilli podkreśla także, że w omawianym fragmencie Gaius chciał - być może ze względu na dydaktyczny charakter wypowiedzi - wyraźnie odróżnić strzeżenie (custodia) obecne w depozycie od obowiązku zagwarantowania strzeżenia (custodiam praestare), występującego w kontrakcie najmu i użyczenia ${ }^{36}$.

Dotychczas omawiane interpretacje fragmentu Instytucji Gaiusa 3,205-207, poza pierwszą wskazującą na custodia w funkcji obiektywnego kryterium odpowiedzialności, przyjmowały znaczenie custodiam praestare jako szczególne go typu zobowiązania do strzeżenia rzeczy. Odpowiedzialność za jego niespełnienie była w każdym z nich niezależna od winy dłużnika. Odczytanie tekstu przy takich założeniach odnośnie znaczenia custodiam praestare nie budzi poważniejszych zastrzeżeń.

Odmienne i bardziej współczesne postrzeganie zobowiązania do strzeżenia proponuje MacCormack. W jego interpretacji Gaius przypisywałby odpowiedzialność wymienianym w źródle dłużnikom jedynie w przypadku winy (culpa). Jurysta nie uznawał za konieczne napisanie tego w Instytucjach, ponieważ zazwyczaj w przypadku kradzieży osoba mająca obowiązek strzeżenia w jakiś sposób zawiniła ${ }^{37}$. Utrata rzeczy nie jest jednak w omawianym ujęciu wystarczającym dowodem niespełnienia zobowiązania do strzeżenia rzeczy, określanego przez custodiam praestare. Zdaniem autora nie można bowiem zakładać, że

\footnotetext{
${ }^{35}$ V. ARANGIO-Ruiz, Responsabilità contrattuale (cit. przyp. 7), s. 66.

${ }^{36}$ R. CARDILLI, L'obbligazione di 'praestare' (cit. przyp. 4), s. 489.

${ }^{37}$ G. MACCORMACK, 'Custodia' and 'Culpa', «ZSS» 89 (1972), s. 161.
} 
każda kradzież powoduje odpowiedzialność za winę w strzeżeniu. MacCormack przypisuje ciężar dowodu folusznikowi, krawcowi czy komodatariuszowi i podkreśla, że jeżeli wykażą brak winy (własnej czy podwładnych) to nie będą ponosić odpowiedzialnościs ${ }^{38}$.

Przedstawiona interpretacja nie wydaje się przekonująca. W tym miejscu warto podkreślić słuszne spostrzeżenia Arangio-Ruiza, iż dla jurysty bez znaczenia pozostają okoliczności utraty rzeczy. Gaius w podręczniku skierowanym dla studentów starał się być tak precyzyjny, jak to tylko możliwe. Skoro nie wspomina o winie dłużnika, ani tym bardziej o rozkładzie ciężaru dowodu, to znaczy, że w omawianej sytuacji nie miały one najmniejszego znaczenia. Przypuszczenie, jakoby jurysta miał na myśli jedynie kradzieże, w których dłużnik zawinit, lecz nie uznał za stosowne podzielić się z uczniami informacją o tak fundamentalnym znaczeniu, zarówno teoretycznym jak i praktycznym, jest bardzo ryzykowne. Pogląd MacCormacka nie tylko nie znajduje potwierdzenia w analizowanym źródle, ale pozostaje w sprzeczności z treścią wypowiedzi Gaiusa ${ }^{39}$.

\section{EWOLUCJA ZOBOWIĄZANIA DO STRZEŻENIA RZECZY W PRAWIE KLASYCZNYM}

Zobowiązanie do strzeżenia określane przez custodiam praestare podlegało ewolucji i już od czasu najdawniejszych prawników stawiano pytanie o jego granice. W omówionym fragmencie Instytucji Gaiusa widoczny jest przede wszystkim aspekt ochrony przed kradzieżą rzeczy. Kluczowym tekstem dla odtworzenia rozwoju zakresu zobowiązania określanego przez custodiam praestare jest fragment 5 księgi komentarza Ulpiana do edyktu. Jurysta przedstawia w nim polemikę między Marcellusem a Julianem. Ponieważ pogląd Juliana znajduje się również jako samodzielna wypowiedź w innym miejscu kompilacji źródła cytuję wspólnie:

\footnotetext{
${ }^{38}$ G. MACCORMack, 'Custodia' and 'Culpa' (cit. przyp. 37), s. 161.

${ }^{39}$ G. MACCORMACK, 'Custodia' and 'Culpa' (cit. przyp. 37), s. 162.
} 
D. 13,6,19 (Iul. 1 dig.): Ad eos, qui servandum aliquid conducunt aut utendum accipiunt, damnum iniuria ab alio datum non pertinere procul dubio est: qua enim cura aut diligentia consequi possumus, ne aliquis damnum nobis iniuria det? $?^{40}$

D. 19,2,41 (Ulp. 5 ad ed.): Sed de damno ab alio dato agi cum eo non posse Iulianus ait: qua enim custodia consequi potuit, ne damnum iniuria ab alio dari possit? sed Marcellus interdum esse posse ait, sive custodiri potuit, ne damnum daretur, sive ipse custos damnum dedit: quae sententia Marcelli probanda est ${ }^{41}$.

We fragmencie pochodzącym z pierwszej księgi Digestów Julian stwierdza kategorycznie, że osoby najęte do strzeżenia rzeczy czy komodatariusze nie odpowiadają za szkody wyrządzone przemocą przez osoby trzecie. Uzasadniając swoje stanowisko jurysta stawia retoryczne pytanie: jaka bowiem opieka i staranność jest w stanie uchronić nas od bezprawnej szkody wyrządzonej przez osobę trzecią? (qua enim cura aut diligentia consequi possumus, ne aliquis damnum nobis iniuria det?)

W pierwszej części drugiego źródła Ulpian przytacza powyższy pogląd Juliana. Ponownie uzasadnieniem stanowiska jurysty jest retoryczne pytanie, dotyczące niemożliwości zapobieżenia szkodzie poprzez strzeżenie (qua enim custodia consequi potuit, ne damnum iniuria ab alio dari possit?) Marcellus nie zgadzał się z tym zapatry-

${ }^{40}$ Osoby najęte do strzeżenia czegoś bądź przyjmujące rzecz do używania bez wątpienia nie ponoszą odpowiedzialności za szkody wyrządzone przemocą przez osobę trzecią: jakąż bowiem opieką czy starannością możemy zapewnić, by ktoś nie wyrządził nam bezprawnie szkody?

${ }^{41}$ Ale Julian uważa, że nie można wnosić przeciw niemu [os. najęta do strzeżenia/komodatariusz] skargi z powodu szkody wyrządzonej przez osobę trzecią: jak bowiem za pomocą strzeżenia można zapewnić, by ktoś nie wyrządził nam bezprawnie szkody? Marcellus twierdzi jednak, że czasem można [wnieść skargę], czy to gdy mógł ustrzec, by nie wyrządzono szkody, czy to gdy sam strzegący uczynif szkodę. ten pogląd Marcellusa trzeba uznać za słuszny. 
waniem. Zdaniem tego ostatniego jurysty czasem osoba zobowiązana do strzeżenia będzie odpowiedzialna za szkody wyrządzone przez osobę trzecią. Na przykład wówczas, gdy strzeżenie pozwoliłoby uchronić rzecz od zniszczenia bądź jeżeli sam strażnik (ipse custos) był sprawcą szkody ${ }^{42}$.

Istotą sporu Juliana z Marcellusem jest pytanie co można osiągnąć za pomocą strzeżenia. Podstawowym problemem w interpretacji omawianego źródła jest wyjaśnienie myśli Juliana, określenie na jakiej podstawie jurysta tak kategorycznie wyklucza możliwość uniknięcia szkody wyrządzonej przez osobę trzecią za pomocą strzeżenia? Odpowiedź dana przez Cannatę opiera się na założeniu, że zobowiązanie do strzeżenia posiadało dla Juliana bardzo precyzyjnie określone granice. Osoba zobowiązana do custodiam praestare musiała zapewnić ochronę wyłącznie przed szkodami dokonanymi bez uźycia przemocy ${ }^{43}$. Pozostaje jednak problem wykluczenia przez Juliana wszystkich możliwych przypadków szkody wyrządzonej przez osoby trzecie. Dlaczego komodatariusz ma być zwolniony z odpowiedzialności, jeżeli ktoś rzeczy nie kradnie, lecz ją niszczy, a sama obecność strzegącego uchroniłaby rzecz od szkody ${ }^{4}$ ? W wypowiedzi Juliana damnum iniuria datum jest traktowane ogólnie. Jeżeli rozpatrujemy zagadnienie na tym poziomie, stwierdzenie jurysty przestaje być tak bardzo kontrowersyjne. Zazwyczaj nie można bowiem unik-

${ }^{42}$ Por. odnośnie do interpretacji ipse custos w D. 19,2,41 R. KNÜTEL, Die Haftung für Hilfspersonen im römischen Recht, «ZSS» 100 (1983), s. 413-14; B. ALBANESE, D. 13,6,19 e D. 19,2,41 nel quadro dei problemi della 'custodia', [w:] Studi Grosso, I, Torino 1968, s. 88 i 88 przyp. 19; C.A. CANNATA, Sul problema (cit. przyp. 21), s. 34; P. VOCI, 'Diligentia', 'custodia', 'culpa': i dati fondamentali, «SDHI» 56 (1990), s. 78.

${ }^{43}$ Wskazuje na to utrzymana $w$ tym samym tonie wypowiedź innego jurysty z tego okresu: D. 19,1,31pr. (Nerva 3 membr.): Si ea res, quam ex empto praestare debebam, vi mihi adempta fuerit: quamvis eam custodire debuerim, tamen propius est, ut nihil amplius quam actiones persequendae eius praestari a me emptori oporteat, quia custodia adversus vim parum proficit ...

${ }^{44}$ Warto podkreślić, że jest to właśnie wątpliwość wyrażana przez Marcellusa, którą współcześnie powielają ALBANEsE oraz VocI, por. wcześniej przyp. 42. 
nąć szkody wyrządzonej przemocą za pomocą biernej ochrony konieczne jest aktywne powstrzymywanie sprawcy. Perspektywa Juliana daje się wytłumaczyć pochodzeniem wypowiedzi z pierwszej księgi digestów. Zobowiązanie do strzeżenia na pewno nie było głównym tematem rozważań.

Kategoryczność stwierdzenia Juliana dowodzi pewności jurysty odnośnie granic zobowiązania do strzeżenia. W tym okresie custodia była rozumiana jako bierna ochrona nie wymagająca czynnego przeciwstawiania się zagrożeniom. Podstawowa zasada brzmiała: custodia adversus vim parum proficit. Z praktycznego punktu widzenia custodia pozostawała więc ochroną przed kradzieżą (furtum). Być może rozważane były inne zdarzenia powodujące szkody dla których uniknięcia wystarczy sama obecność strzegącego - jak na przykład zniszczenie rzeczy przez myszy (D. 19,2,13,6). Z zakresu odpowiedzialności bez wątpienia wykluczone były: rabunek (D. 19,1,31 pr.); pauperies jako szkoda wyrządzona przez zwierzę (D. 9,1,2 pr.); a także szkoda wyrządzona przemocą przez osobę trzecią (damnum iniuria datum) ${ }^{45}$.

Potwierdzeniem powyższych stwierdzeń są poglądy jurystów epoki Hadriana na dostępność actio ex lege Aquilia i actio furti. $\mathrm{O}$ ile skarga $z$ tytułu kradzieży była dla osoby odpowiedzialnej za strzeżenie rzeczy zawsze dostępna ${ }^{46}$, to w przypadku skargi akwiliańskiej wyłącznie legitymowanym pozostawał wlaściciel ${ }^{47}$. Takie ukształtowanie odpowiedzialności za strzė̇enie rzeczy jest uzasadnione $z$ praktycznego punktu widzenia. Podczas gdy zazwyczaj nie wiadomo kto ukradł rzecz, odnalezienie kogoś kto dokonał dam-

${ }^{45}$ D. 19,2,41; zgodzić się trzeba z Albanese, że nie chodzi o przemoc względem strzegącego, jak w przypadku rabunku, tym niemniej aby zapobiec damnum iniuria datum zazwyczaj nie wystarczy bierna ochrona rzeczy.

${ }^{46}$ Niemal wszystkie źródła omawiające zobowiązanie do custodiam praestare przyznają jednocześnie odpowiedzialnemu za strzeżenie legitymacje do actio furti, por. dla przykładu analizowany wcześniej G. 3,205-207.

${ }^{47}$ D. 9,2,11,9 (Ulp. 18 ad ed.) Eum cui vestimenta commodata sunt non posse, si scissa fuerint, lege Aquilia agere Iulianus ait, sed domino eam competere. 
num iniuria datum jest łatwiejsze i właściciel ma realną szansę wystąpić z actio ex lege Aqulia ${ }^{4}$.

Marcellus łamie wcześniejszy schemat rozumowania przez wprowadzenie szkody, której można było zapobiec poprzez strzeżenie. Myśl jurysty można opisać następująco: Julian wyraża się nieprecyzyjnie twierdząc, że osoba zobowiązana do strzeżenia nigdy nie powinna odpowiadać za damnum iniuria datum. Jeżeli szkody można było uniknąć za pomocą custodia, bądź jeżeli zostala spowodowana przez pozostawionego strażnika, to komodatariusz powinien ponosić odpowiedzialność.

Problemem rozważanym przez Marcellusa nie jest wyłącznie zobowiązanie do strzeżenia, lecz generalnie odpowiedzialność komodatariusza za damnum iniuria datum. Marcellus dokładnie analizuje poboczną wypowiedź Juliana ${ }^{49}{ }^{50}$. Komentarz Marcellusa pozostaje bezpośrednio związany z wcześniejszą argumentacją ${ }^{51}$ :

D. 19,2,40 (Ulp. 5 ad ed.): ... qua enim custodia consequi potuit, ne damnum iniuria ab alio dari possit?... Sive custodiri potuit ne damnum daretur...

Stwierdzenie, że czasem można uchronić rzecz od szkody poprzez strzeżenie prowadzi do rozważania poszczególnych przypadków damnum iniuria datum. Najistotniejsze w tej chwili staje się określenie kryterium, według którego należy oceniać czy danej szkody można było uniknąć. Sive custodiri potuit, ne damnum daretur nie oznacza, że strzegący nie dolożył wystarczającej staranności

${ }^{48}$ Prawdopodobnie Julian zdawał sobie sprawę z możliwości uniknięcia damnum iniuria datum w szczególnych okolicznościach, lecz nie chcial rozszerzać zakresu obiektywnej odpowiedzialności za strzeżenie rzeczy; por. R. KNỨTEL, Die Haftung für Hilfspersonen (cit. przyp. 42), s. 413.

${ }^{49} \mathrm{Nie}$ wiadomo co było głównym tematem w jego rozważaniach, prawdopodobnie problem w jakiś sposób związany z pierwszą księgą edyktu De in ius vocando, por. C.A. CANNATA, Ricerche (cit. przyp. 8), s. 77.

${ }^{50}$ C.A. Cannata, Ricerche (cit. przyp. 8), s. 80.

${ }^{51}$ C.A. CANnATA, Sul problema (cit. przyp. 21), s. 34. 
(diligentia) w strzeżeniu rzeczy ${ }^{52}$. Dla Marcellusa uległo rozszerzeniu samo znaczenie terminu custodia. Jego zdaniem aktywność określana w ten sposób wystarczała, aby w szczególnych okolicznościach (interdum) uchronić rzecz od szkody wyrządzonej siłą przez osobę trzecią. Zrelatywizowanie problemu strzeżenia rzeczy w odniesieniu do damnum iniuria datum stworzyło konieczność ustalenia na nowo granic zobowiązania określanego przez custodiam praestare $^{53}$. Ostatecznie odpowiedzialność za strzeżenie była ujmowana jako odpowiedzialność za utratę rzeczy, a jedyną okolicznością zwalniającą pozostawała siła wyższa (vis maior) ${ }^{54}$. Jako przykład możemy przytoczyć fragment dotyczący actio pigneraticia:

D. 13,7,13,1 (Ulp. 38 ad ed.) Venit autem in hac actione et dolus et culpa, ut in commodato: venit et custodia: vis maior non venit ${ }^{55}$.

\section{OD CUSTODIAM PRAESTARE DO DILIGENTIA IN CUSTODIENDO -} EWOLUCIA ZOBOWIĄZANIA DO STRZEŻENIA W OKRESIE POKLASYCZNYM

Ostatnim etapem rozwoju zobowiązania do strzeżenia rzeczy byto przejście w okresie poklasycznym od zobowiązania ocenianego w kategoriach rezultatu (custodiam praestare) do zobowiązania, w którym odpowiedzialność przypisywana byla na podstawie staranności dłużnika w strzeżeniu (diligentia in custodiendo). Pierwsze pytanie wymagające odpowiedzi brzmi: dlaczego model klasyczny okazał się niewystarczający? Wydaje się, że prawnicy okresu pokla-

${ }^{52}$ G. MACCormack, 'Custodia' and 'Culpa' (cit. przyp. 37), s. 171 i 172 uznaje za bardziej poprawne sformułowanie Juliana z D. 13,6,19, a w tekście Marcellusa dostrzega aluzję do niewystarczającej staranności strzegącego.

${ }^{53}$ Custodia przestaje być terminem ściśle zdefiniowanym, oznaczającym najogólniej rzecz ujmując wylącznie ochronę przed zwykła kradzieżą (furtum).

${ }^{54}$ Por. C.A. Cannata, Ricerche (cit. przyp. 8), s. 111-113.

${ }^{55} \mathrm{~W}$ zakres odpowiedzialności przy tej skardze wchodzi podstęp i wina, tak jak przy użyczeniu także strzeżenie rzeczy, nie wchodzi siła wyższa. 
sycznego nie rozumieli dobrze zasad odpowiedzialności za strzeżenie rzeczy ${ }^{56}$. Zobowiązanie określane przez custodiam praestare było już w pełni ukształtowane i związek między odpowiedzialnością a świadczeniem, tak silny na początku - świadczenie ochrony, odpowiedzialność za kradzież - przestawał być wyczuwalny przy odpowiedzialności za wszelkie zdarzenia z granicą siły wyższej. Stąd potrzeba wprowadzenia dobrze sobie znanego kryterium staranności (diligentia) jako podstawy odpowiedzialności ${ }^{57}$.

Jako przykład swobody z jaką kryterium staranności wypierało klasyczną custodia może posłużyć zmiana w treści wypowiedzi Juliana ${ }^{58}$ :

D. 19,2,41 (Ulp. 5 ad ed.): qua enim custodia consequi potuit, ne damnum iniuria ab alio dari possit?

D. 13,6,9 (Iul. 1 dig.): qua enim cura aut ditigentia consequi possumus, ne aliquis damnum nobis iniuria det?

Warto podkreślić, że wprowadzenie kryterium diligentia w miejsce custodia świadczy pośrednio o tym, że sformułowanie custodiam praestare wyznaczało także reżim odpowiedzialności. Wydawać by się mogło, że przedstawiana zmiana jest fundamentalna ustanawia odpowiedzialność za winę w miejsce odpowiedzialności obiektywnej.

${ }^{56}$ Por. V. Arangio-Ruiz, Responsabilità contrattuale (cit. przyp. 7), s. 89-92.

${ }^{57} \mathrm{~W}$ pierwszym zdaniu analizowanego wcześniej D. 13,6,5,9 (Ulp. 28 ad ed.) Usque adeo autem diligentia in re commodata praestanda est, ut etiam in ea, quae sequitur rem commodatam, praestari debeat: ut puta equam tibi commodavi, quam pullus comitabatur: etiam pulli te custodiam praestare debere veteres responderunt uznaję odniesienie do diligentia za poklasyczne. Nie jest przekonujący argument MACCORMACKA, przejęty przez CARDILLEGO, że nie sposób wytłumaczyć, dlaczego kompilatorzy zmienili jedynie początek źródła, pozostawiając jednocześnie custodia w jego fragmencie końcowym. Działanie kompilatorów jest zrozumiałe, wystarczy bowiem zauważyć, że dla uzyskania wrażenia odpowiedzialności opartej na podstawie winy $w$ omawianym fragmencie wystarczyła zmiana jedynie pierwszego terminu.

${ }^{58}$ C.A. Cannata, Sul problema (cit. przyp. 21), s. 60; zestawienie przykładowych źródeł por. C.A. CANnATA, Ricerche (cit. przyp. 8), s. 58-59. 
Źródła ukazują jednak zupełnie inny obraz. Zmiana podstawy odpowiedzialności nie prowadziła do zmiany samego reżimu. Zakres odpowiedzialności dłużnika pozostał niezmienny, niezależnie od posługiwania się nową terminologią ${ }^{59}$ :
D. 18,6,2,1 (Gai. 2 cott. rer.) Custodiam autem ante admetiendi diem qualem praestare venditorem oporteat, utrum plenam, ut et diligentiam praestet, an vero dolum dumtaxat, vide- amus. et puto eam diligentiam venditorem exhibere debere, ut fatale damnum vel vis magna sit excusatum ${ }^{60}$.

Fragment dotyczy obowiązku strzeżenia rzeczy przez sprzedawcę i pomijam analizę jego treścí ${ }^{61}$, koncentrując się wyłącznie na sposobie przedstawienia odpowiedzialności. W omawianym fragmencie zobowiązanie do strzeżenia jest przedstawione jako pewna forma diligentia ${ }^{62}$. Sprzedawca musiał wykazywać się starannością

\footnotetext{
${ }^{59}$ Por. także D. 44,7,1,4 (Gai. 2 cott. rer.): Et ille quidem qui mutuum accepit, si quolibet casu quod accepit amiserit, nihilo minus obligatus permanet: is vero qui utendum accepit, si maiore casu, cui humana infirmitas resistere non potest, veluti incendio ruina naufragio, rem quam accepit amiserit, securus est. alias tamen exactissimam diligentiam custodiendae rei praestare compellitur, nec sufficit ei eandem diligentiam adhibere, quam suis rebus adhibet, si alius diligentior custodire poterit. sed et in maioribus casibus, si culpa eius interveniat, tenetur, veluti si quasi amicos ad cenam invitaturus argentum, quod in eam rem utendum acceperit, peregre proficiscens secum portare voluerit et id aut naufragio aut praedonum hostiumve incursu amiserit.

${ }^{60}$ Zobaczmy jaką ochronę rzeczy musi świadczyć sprzedawca przed terminem odmierzenia, czy pełną, tak że musi dokładać staranności czy jest odpowiedzialny tylko za podstęp (dolus). I sądzę że musi dokładać takiej staranności, że tylko szkoda nie możliwa do uniknięcia czy siła wyższa będą zwalniały go z odpowiedzialności.

${ }^{61} \mathrm{~W}$ źródle problemem jest obowiązek strzeżenia przed odmierzeniem, tzn. przed konkretyzacją - innymi słowy, pytanie dotyczy konieczności strzeżenia całego zapasu towaru. Obowiązek strzeżenia przy kontrakcie sprzedaży wymaga rozważenia wielu aspektów, w szczególności relacji między przejściem ryzyka utraty rzeczy (periculum est emptoris) a powstaniem gwarancyjnego zobowiązania określanego przez custodiam praestare po stronie sprzedawcy po zawarciu kontraktu.

${ }^{62}$ Poprzednio analizowany fragment Instytucji G. 3,205-207 jednoznacznie dowodzi, że jurysta nie postrzegał zobowiązania określanego przez custodiam prae-
} 
w strzeżeniu. Staranność jego była jednak bardzo szczególna - możemy nawet powiedzieć, że była to staranność absolutna - skoro jedynie siła wyższa mogła uwolnić sprzedawcę od odpowiedzialności (et puto eam diligentiam venditorem exhibere debere, ut fatale damnum vel vis magna sit excusatum).

Zobowiązanie do strzeżenia ujęte w nową formę diligentia in custodiendo nie zmienia swojej podstawowej cechy - pozostaje zobowiązaniem o charakterze gwarancyjnym. Uwolnienie się od odpowiedzialności za custodia może polegać na wykazaniu siły wyższej jako przyczyny utraty rzeczy, ale nigdy nie na wykazaniu staranności postępowania samego strzegącego ${ }^{63}$. Zwolennicy odpowiedzialności za strzeżenie pojmowanej jako odpowiedzialność za winę w strzeżeniu nie dostrzegają, jak bardzo zmieniają zakres pojęcia culpa ${ }^{64}$.

Sposób przedstawienia problemu strzeżenia przez prawników poklasycznych został zaakceptowany przez kompilatorów Justyniańskich, dlatego w tekście Digestów tak często spotykamy diligentia w miejscach, gdzie pierwotnie wystarczało określenie custodiam praestare. Podstawą dokonywanych zmian było oparcie systemu odpowiedzialności w całej kodyfikacji na kryterium winy dłużnika. Unifikacja w zakresie zobowiązania do strzeżenia rzeczy była jednak czysto terminologiczna.

stare w kategorii staranności strzeżenia. Dla Gaiusa byla to także odpowiedzialność tylko za furtum (G. 3,205-207); granica vis maior prawdopodobnie pochodzi od Paulusa, natomiast w analizowanym tekście prawnicy poklasyczni przedstawiają zobowiązanie do strzeżenia w jego ostatecznym kształcie.

${ }^{63}$ Inaczej w przypadku odpowiedzialności opartej na winie, kiedy wystarcza wykazanie własnej staranności, por. np. D. 13,6,5,7 analizowany przez C.A. CANNATA, Sul problema (cit. przyp. 21), s. 59.

${ }^{64}$ G. MacCormack, 'Custodia' and 'Culpa' (cit. przyp. 37), s. 168 przyp. 59 wyczuwając istotę problemu stwierdza, że wina musiała polegać na czymś więcej niż tylko na nie zwróceniu rzeczy, lecz nie rozwija swojego konceptu i ostatecznie nie dowiadujemy się na czym. Inaczej P. VocI, 'Diligentia', 'custodia', 'culpa': $i$ dati fondamentali (cit. przyp. 42), s. 75, który stwierdza bezpośrednio, że winą jest nieuchronienie rzeczy: "Il debitore che venga meno al obbligo di custodia comette colpa". 


\section{Podsumowanie}

Poznanie znaczenia pojawiającego się często w pismach jurystów zwrotu custodiam praestare stanowiło trudny problem dla badaczy prawa rzymskiego, który pozostaje także obecnie bez ostatecznej odpowiedzi. Dostępne źródła często wskazywały na treść zobowiązania. Odpowiedzialność była jednak czasem przedstawiana jako staranność w strzeżeniu (D. 18,6,2,1), a czasem bezspornie niezależna od działania osoby zobowiązanej (G. 2,205-207). Przywiązanie doktryny do współczesnych kategorii prawnych - za Justynianem łączących z reguły odpowiedzialność dłużnika z jego winą - doprowadziło do stworzenia dwóch przeciwstawnych teorii. Pierwsza z nich została ugruntowana przez Arangio-Ruiza. Obiektywna odpowiedzialności za custodia wykluczała istnienie zobowiązania do strzeżenia. Koncepcja opozycyjna, akcentując znaczenie custodia jako należnego świadczenia polegającego na ochronie rzeczy, w celu zachowania logiki współczesnych rozwiązań, musiała odrzucić obiektywny charakter odpowiedzialności.

Wydaje się, że custodiam praestare oznaczało w prawie klasycznym zobowiązanie do strzeżenia rzeczy o charakterze gwarancyjnym ${ }^{65}$. Najdawniejsi prawnicy poszukiwali granic tego zobowiązania w kontrakcie użyczenia, rozważając konieczność strzeżenia niewolników i rzeczy towarzyszącej względem samego przedmiotu użyczenia (D. $13,6,5,6$ i D. 13,6,5,9). Ewolucja zobowiązania polegała na rozszerzaniu zakresu pojęcia custodia. Na początku osoba zobowiązana do strzeżenia odpowiadała wyłącznie za kradzież rzeczy (D. 13,6,19) ${ }^{66}$. Marcellus wprowadził odpowiedzialność także za niektóre szkody, jeżeli strzeżenie wystarczyłoby dla ich uniknięcia (D. 19,2,41). Ostatecznie odpowiedzialność przy zobowiązaniu okre-

${ }^{65}$ C.A. Cannata, Ricerche (cit. przyp. 8), s. 129; interpretacja przejęta potem przez najnowsze prace CARDILLEGO i DE ROBERTISA.

${ }^{66}$ Ewentualnie inne zdarzenia możliwe do uniknięcia za pomocą biernej ochrony, jak uszkodzenie ubrania przez myszy w D. 19,2,13,6. 
ślanym przez custodiam praestare wyłączała jedynie szkoda będąca wynikiem działania siły wyższej (D. 13,7,13,1).

W okresie poklasycznym postrzegano zobowiązanie do strzeżenia w kategoriach staranności dłużnika (diligentia in custodiendo), jednak mimo to zobowiązanie określane wcześniej przez custodiam praestare nie straciło swojego gwarancyjnego charakteru. Od osoby zobowiązanej do strzeżenia wymagano staranności absolutnej i nadal uwolnienie się od odpowiedzialności było możliwe tylko w przypadku, gdy szkoda wynikała z okoliczności stanowiących siłę wyższą (D. 18,6,2,1).

\section{'CUSTODIAM PRAESTARE - THE EVOLUTION OF AN OBLigATION \\ to Guarantee the Safekeeping of an Object in the Roman LaW}

\section{Summary}

This article focuses on the evolution of an obligation to guarantee the safekeeping of an object (custodiam praestare). This kind of a duty arose in all contracts in which the debtor received things for his own interest. The limits of liability were discussed by the earlier jurists (veteres) in the contract of loan for use (commodatum). In the first analyzed text (D. 13,6,5,6) the problem concerned the necessity of safekeeping of a slave loaned for use; the second case (D. 13,6,5,9) discussed the duty of safekeeping of a thing accompanying the main object of a contract. The argumentation adopted by the veteres proves that already for the early jurists the very obligation to keep safe of an object in commodatum was unquestionable: they were rather to decide arising troublesome controversies.

The meaning of custodiam praestare as an obligation to guarantee the safekeeping of an object and the problem when such an obligation arose was analyzed by Gaius in his commentary to the provincial edict (D. 19,2,40 and D. 4,9,5 pr.). The jurist laid down that the duty to keep an object safe is not a principal obligation in agreements contracted with the seamen, inn- and stable-keepers, they were liable for the safekeeping in 
the same way as fullers and tailors. The obligation custodiam praestare in case of fullo and sarcinator was clarified in Gaius' Institutiones (G. 3,205-207): a party was liable for safekeeping of an object, when it received the object for its own interest.

Custodiam praestare evolved by way of an interpretation of the term custodia. The first concept of liability for safekeeping of an object was restricted to theft (D. 13,6,19) and it did not include damage induced by a third party. Subsequently, Marcellus introduced a wider interpretation of safekeeping: a party would be liable for not returning the object kept, as long as the activity of custodia would have been enough to avoid an unlawful damage (D. 19,2,41)

This understanding broadened the limits of liability: eventually, towards the end of the classical period custodia apparently covered every loss but for the case of force majeure (D. 13,7,13,1). In the postclassical period there seems to have occurred a change in the regime of custodia liability. Many a text brings a new formulation: instead of custodiam praestare we find the expression diligentia in custodiendo, thus one could think that this kind of liability was then based on negligence. Nevertheless, this terminological alteration did not affect the limits of liability. The person under the obligation to keep an object safe remained liable for the loss thereof and could only be exonerated by proving that the loss was due to vis maior (D. $18,6,2,1)$. 